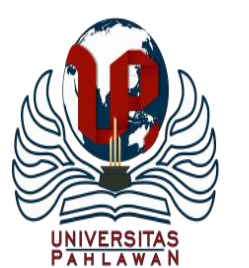

Edukatif : Jurnal Ilmu Pendidikan Volume 3 Nomor 4 Tahun 2021 Halm 2141 - 2148

EDUKATIF: JURNAL ILMU PENDIDIKAN

Research \& Learning in Education

https://edukatif.org/index.php/edukatif/index

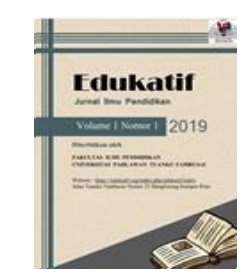

\section{Pengembangan Media Pembelajaran Berbasis Teknologi Berbantuan Adobe Flash Cs6 untuk Pembelajaran pada Masa Pandemi Covid-19}

\author{
Lola Afriani ${ }^{1 凶}$, Yanti Fitria ${ }^{2}$ \\ Universitas Negeri Padang, Indonesia ${ }^{1,2}$ \\ E-mail : lolaafriani17@gmail.com ${ }^{1}$, yanti_fitria@ fip.unp.ac.id ${ }^{2}$
}

\begin{abstract}
Abstrak
Penelitian ini dilatarbelakangi oleh perlunya inovasi berupa media pembelajaran yang tepat untuk proses pembelajaran pada masa pandemi covid 19. Tujuan penelitian ini adalah mengembangkan media pembelajaran berbasis teknologi berbantuan adobe flash cs 6 yang valid untuk digunakan pada masa pandemi covid 19 . Penelitian ini merupakan penelitian pengembangan dengan model 4-D. penelitian ini menyatakan bahwa media yang dikembangkan dikategorikan sangat valid oleh pakar ahli. Hal ini membuktikan bahwa media pembelajaran yang dikembangkan sangat layak untuk digunakan. Implikasi dari penelitian ini adalah dapat dijadikan sebagai referensi dalam pengembangan media pembelajaran pada masa pandemi covid-19.
\end{abstract}

Kata Kunci: media pembelajaran, teknologi, adobe flash, cs6.

\title{
Abstract
}

This research is motivated by the need for innovation in the form of appropriate learning media for the learning process during the covid 19 pandemic. The purpose of this research is to develop a technology-based learning media assisted by adobe flash cs 6 that is valid for use during the covid 19 pandemic. This research is a development research with 4-D models. This study states that the developed media is categorized as very valid by experts. This proves that the learning media developed is very feasible to use. The implication of this research is that it can be used as a reference in the development of learning media during the COVID-19 pandemic.

Keywords: learning media, technology, adobe flash, cs6.

Copyright (c) 2021 Lola Afriani, Yanti Fitria

$\triangle$ Corresponding author

Email : lolaafriani17@gmail.com

DOI : https://doi.org/10.31004/edukatif.v3i4.1171 
2142 Pengembangan Media Pembelajaran Berbasis Teknologi Berbantuan Adobe Flash Cs6 untuk Pembelajaran Pada masa pandemi Covid-19- Lola Afriyani, Yanti Fitria

DOI : https://doi.org/10.31004/edukatif.v3i4.1171

\section{PENDAHULUAN}

Dunia sedang mengalami masa pandemi covid-19. Pandemi covid-19 memiliki dampak tidak hanya saja terhadap kesehatan masyarakat namun juga berdampak kepada system ekonomi, sosial, budaya bahkan juga berdampak kepada system Pendidikan (Sari, 2021; Hendri et al, 2021). Pandemi covid-19 ini berdampak kepada proses pembelajaran baik dari proses pembelajara di Lembaga pendidikan anak usia dini sampai kepada proses pembelajaran di perguruan tinggi (Siripongdee et al, 2020). Berdasarkan kajian literatur ditemukan fakta bahwa banyak negara yang berada didunia melakukan penutupan sekolah (Aji, 2020). UNESCO menyatakan hamper lebih dari 900 juta siswa didunia mengalami dampak proses penutupan dimasa pandemi covid-19 ini (Soewardini et al, 2021).

Proses penutupan Lembaga dan intitusi pendidikan ini berpengaruh terhada proses pembelajaran dan system kurikulum yang selama ini telah digunakan. Selama proses pandemi covid-19 ini banyak Lembaga pendidikan yang menyesuaikan system pembelajarannya seperti penghapusan ujian nasional untuk tingkat sekolah dasar dan menengah, meniadakan penelitian sebagai tugas akhir mahasiswa, meniadakan pertukaran pelajar dan study tour. Semua kebijakan ini merupakan sebuah proses untuk menerapkan physical distancing bagi masyarakat.

Physical distancing merupakan upaya pemerintah dalam mengurangi penyebaran virus corana dengan membatasi kegiatan langsung masyarakat (Galea et al, 2020; Jones et al, 2020). Konsep ini lah yang melatarbelakangi lahirnya istilah learning form home atau yang dikenal juga dengan system belajar dari rumah. Sistem belajar dari rumah menuntut seluruh lembaga pendidikan untuk dapat meniadakan kegiatan di sekolah (Astini, 2020; Zainudin and Sama, 2020). Hal ini menuntut lembaga pendidikan untuk dapa memberikan alternatif pembelajaran berupa inovasi untuk siswa dalam proses belajar dari rumah tanpa mengurangi esensi pencapaian tujuan pembelajaran.

Inovasi pada masa pandemi covid-19 akan membuka kesempatan untuk memulai paradigma pembelajaran yang baru yaitu melaksanakan proses pembelajaran tanpa harus bertatap muka secara langsung (Hendri et al, 2019; Astini, 2020). Maka disinilah system teknologi informasi memiliki peranan penting dalam proses pembelajaran dari rumah atau dikenal juga dengan istilah online learning (Nopitasari et al, 2021). Proses pembelajaran dari rumah dapat disiasati dengan menggunakan teknologi smartphone maupun memanfaatkan perangkat computer (Pakpahan and Fitriani, 2020; Salsabila et al, 2020). Dengan menggunakan teknologi ini diharapkan dapat meningkatkan keaktifan siswa dalam proses pembelajaran dari rumah.

Pada umumnya penggunaan teknologi sudah sering digunakan pada proses pembelajaran. Bahkan siswa sekolah dasar pun sudah mulai menguasai teknologi seperti smarphone maupun perangkat computer. Penggunaan kedua teknologi tersebut menjadi popular dikalangan masyarakat. Oleh sebab itu sudah selayaknya proses pembelajaran pada masa pandemi covid-19 ini memanfaatkan teknologi agar terlaksananya proses pembelajaran yang dapat mencapai tujuan pembelajaran.

Berdasarkan wawancara yang peneliti lakukan ditemukan fakta bahwa proses pembelajaran pada masa pandemic hanya sebatas mengirimkan bahan ajar dan tugas kepada siswa. Guru mengakui bahwa banyak siswa yang mengeluh dikarenakan tidak memahami materi ajar yang diberikan. Selain itu dengan proses pembelajaran melalui pemberian tugas tersebut juga cendrung membosankan sehingga guru menyampaikan banyak tugas yang diberikan tidak dikerjakan oleh siswa.

Berhubungan dengan hal tersebut maka perlunya penyesuaian proses pembelajaran pada masa pandemi covid-19 ini. Salah satu bentuk penyesuaian yang dapat dilakukan adalah dengan mengembangkan media pembelajaran berbasis teknologi yang dapat mempermudah siswa dalam memahami materi pembelajaran tanpa harus bertatap muka langsung dengan guru. Salah satu bentuk penembangan media pembelajaran berbasis teknologi adalah dengan menggembangkan media pembelajaran berbantuan aplikasi Adobe Flash CS 
6. Aplikasi Adobe Flash CS 6 merupakan sebuah aplikasi yang mampu mengembangakn sebuah multimedia interaktif dengan menyajikan tampilan berupa gambar, animasi, prentasi, game dan bahkan dapat menampilkan film (Miaz et al, 2019; Muyaroh and Fajartia, 2017). Adobe Flash CS 6 merupakan aplikasi yang memudahkan guru untuk berinovasi dalam mengembangkan media pembelajaran (Rezeki, 2018).

Beberapa penelitian terkait pengembangan multimedia interaktif telah dilakukan. Penelitian yang dilakukan oleh Muyaroah dan Fajartia (2017) yang telah mengembangkan media pembelajaran dengan bantuan aplikasi adobe flash CS 6 pada pembelajaran biologi untuk siswa SMA yang dinyatakan valid, praktis dan efektif. Penelitian lainnya yaitu penelitian yang dilakukan oleh Yusuf (2015) yang telah mengembangkan media pembelajaran dengan bantuan aplikasi adobe flash cs 6 pada pembelajaran radiasi benda hitam yang valid, praktis dan efektif untuk mahasiswa program studi fisika. Selain itu juga ada penelitian yang dilakukan oleh (Rahmaibu et al (2016) yang menyatakan telah mengembangkan media pembelajaran berbantuan adobe flash cs 6 untuk siswa SD pada pembelajaran PKn yang valid, praktis dan efektif. Namun penelitian ini menjadi berbeda yaitu penelitian ini dikembangkan pada proses pembelajaran tematik untuk siswa sekolah dasar yang disesuaikan dengan proses pembelajaran pada masa pandemic covid-19 yang bersifat online learning. Oleh sebab itu tujuan dari penelitian ini adalah untuk mengembangkan media pembelajaran berbasis teknologi dengan menggunakan bantuan aplikasi adobe flash cs 6 untuk siswa sekolah dasar pada proses pembelajaran di masa pandemi covid-19.

Penelitian ini menjadi penting untuk dilaksanakan mengingat proses pembelajaran di masa pandemi yang memerlukan inovasi yang berhubungan dengan media pembelajaran agar siswa dapat belajar secara maksimal tanpa adanya proses tatap muka langsung dengan guru.

\section{METODE PENELITIAN}

Penelitian ini merupakan penelitian pengembangan dengan menggunakan model 4-D. Model 4-D merupakan model pengembangan dengan tahapan define (pendefinisian masalah), design (perancangan), development (pengembangan) dan dessiminate (penyebaran). Pada tahapan define dilakukan kegiatan analisis kebutuha, analisis siswa, analisis guru dan analisis materi. Pada tahapan design dilakukan kegiatan kegiatan perancangan flowchart dan story board. Pada tahapan development dilakukan kegiatan pengembangan media pembelajaran dan dilakukan uji validitas oleh pakar ahli. Pada tahapan disiminate dilakukan penyebaran media pembelajaran.

Instrumen penelitian ini menggunakan lembar validasi pakar ahli. Pada lembar validasi, pakar ahli melakukan penilaian terhadap media pembelajaran yang dilakukan. Penilaian terdiri dari 4 kategori yaitu 4 untuk nilai sangat baik, 3 untuk nilai baik, 2 untuk nilai kurang baik dan 1 untuk nilai tidak baik. Kemudian hasil penilaian dijumlahkan dan dikonversi berdasarkan tabel berikut :

Tabel 1. Nilai konversi validitas

\begin{tabular}{ll}
\hline \multicolumn{1}{c}{ Skor } & Kategori \\
\hline $81-100$ & Sangat valid \\
\hline $61-80$ & Valid \\
\hline $41-60$ & Cukup valid \\
\hline$<40$ & Tidak valid \\
\hline
\end{tabular}


2144 Pengembangan Media Pembelajaran Berbasis Teknologi Berbantuan Adobe Flash Cs6 untuk Pembelajaran Pada masa pandemi Covid-19- Lola Afriyani, Yanti Fitria

DOI : https://doi.org/10.31004/edukatif.v3i4.1171

\section{HASIL DAN PEMBAHASAN PENELITIAN}

Kegiatan penelitian diawali dengan tahapan define. Tahapan ini bertujuan untuk menemukan landasan permasalahan yang meliputi analisis kebutuhan, analisis siswa, analisis guru dan analisis materi. Analisis kebutuhan dilakukan dengan menghubungkan permasalahan dengan kajian literatur. Pada masa pandemi covid-19 proses pembelajaran dilaksanakan secara daring atau online (Ningsih, 2020). Proses pembelajaran seperti ini bertujuan untuk mengurangi resiko penyebaran virus corona. Proses pembelajaran ini menuntut inovasi guru untuk mengembangkan proses pembelajaran yang memanfaatkan teknologi tanpa harus ada pertemuan tatap muka langsung antara guru dan siswa. Maka diperlukannya sebuah inovasi dalam proses pembelajaran yang dapat melaksanakan proses pembelajaran pada masa pandemi covid-19 (Lestari et al, 2020). Berdasarkan kajian literatur ditemukan salah satu inovasi yang dapat dikembangkan pada masa pandemi covid-19 adalah dengan mengembangkan media pembelajaran berbasis teknologi (Ramdani et al, 2020; Gunawan et al, 2020). Media pembelajaran memilki peranan penting dalam proses penanaman konsep siswa. Kendala yang dirasakan pada proses pembelajaran pada masa pandemic covid-19 ini adalah siswa merasa bosan melaksanakan pembelajaran karena tidak adanya proses interaksi yang terjadi. Hal ini lah yang menjadi landasan utama dalam pengembangan media pembelajaran berbasis teknologi ini.

Pengembangan media teknologi ini menggunakan bantuan aplikasi adobe flash cs 6 . Adobe flash cs 6 dipilih dikarena aplikasi ini memudahkan guru untuk mengembangkan multimedia interaktif dengan memadukan unsur animasi, audio, video dan bahkan dapat memasukan unsur-unsur game (Mayuarah and Fajartia, 2017). Selain Itu banyak nya penelitian yang menyatakan bahwa media pembelajaran yang dikembangkan dengan adobe flash cs 6 dapat meningkatkan pemahaman siswa (Fauziah, 2016; Sswalaganata, 2016). Hal ini lah yang menjadi alasan dipilihnya adobe flash cs 6 sebagai sarana dalam mengembangkan media pembelajaran berbasis teknologi ini.

Selanjutnya dilakukan analisis karakter siswa. Analisis karakter siswa ini dilakukan dengan melakukan penyebaran angket. Adapun hasil angket tersebut dapat dilihat pada tabel berikut:

Tabel 2. Hasil penyebaran angket siswa

\begin{tabular}{lc}
\hline \multicolumn{1}{c}{ Indikator } & Persentase (\%) \\
\hline Memiliki smartphone & 100 \\
\hline Memiliki laptop & 87 \\
\hline Mampu menggunakan smartphone & 100 \\
\hline Mampu menggunakan laptop & 86 \\
\hline
\end{tabular}

Dari tabel 2 terlihat bahwa rata-rata siswa sekolah dasar memiliki teknologi dan mampu mengoperasikannya. Hal ini membuktikan bahwa penerapan media pembelajaran berbasis teknologi dapat diterapkan pada siswa sekolah dasar. Selain itu juga dilakukan analisis karakteristik guru berdasarkan hasil angket yang dilakukan. Adapun hasil angket tersebut dapat dilihat pada tabel berikut:

Tabel 3. Hasil penyebaran angket guru

\begin{tabular}{ll}
\hline Indikator & Persentase (\%) \\
\hline Memiliki smartphone & 100 \\
\hline Memiliki laptop & 100 \\
\hline Mampu menggunakan smartphone & 100 \\
\hline Mampu menggunakan laptop & 100 \\
\hline
\end{tabular}

Dari tabel 3 terlihat bahwa rata-rata guru sekolah dasar memiliki teknologi dan mampu mengoperasikannya. Hal ini membuktikan bahwa penerapan media pembelajaran berbasis teknologi dapat diterapkan pada guru sekolah dasar. Kegiatan selanjutnya adalah melakukan analisis materi. Berdasarkan kesepakatan peneliti dan guru maka materi yang dikembangkan adalah Tema 2 udara bersih bagi Kesehatan.

Tahapan selanjutnya adalah tahapan design. Tahapan design ini bertujuan untuk merancang produk yang dibuat meliputi perancangan flowchart dan story board. Flowschar bertujuan untuk mempermudah siswa 
2145 Pengembangan Media Pembelajaran Berbasis Teknologi Berbantuan Adobe Flash Cs6 untuk Pembelajaran Pada masa pandemi Covid-19- Lola Afriyani, Yanti Fitria

DOI : https://doi.org/10.31004/edukatif.v3i4.1171

untuk mengetahui alur media pembelajaran yang dikembangkan. Adapun contoh flowchart yang dirancang sebagai berikut:

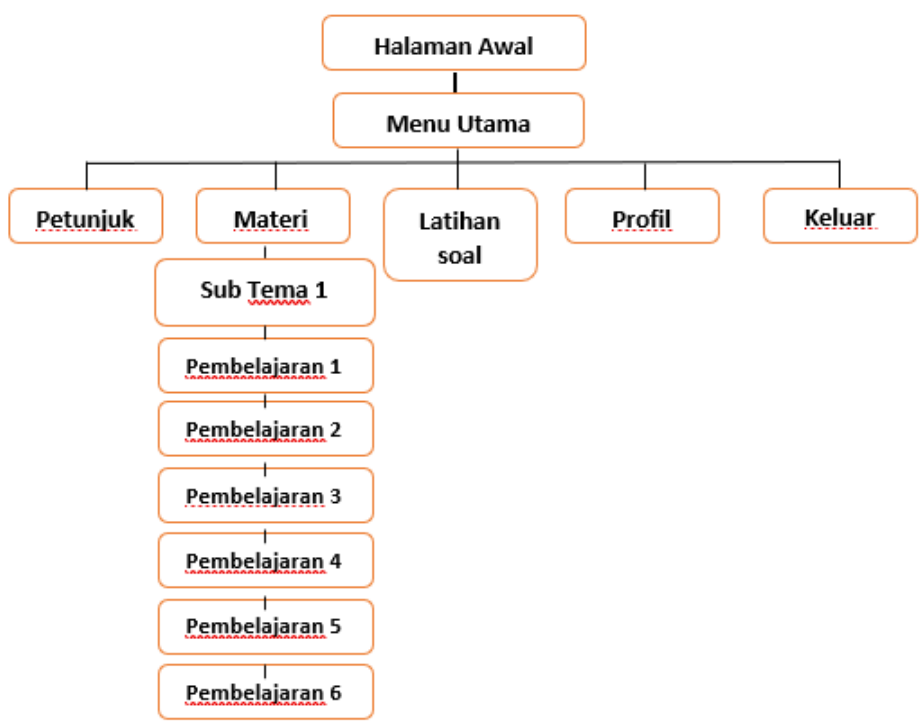

Gambar 1: Desain Flowchart

Selanjutnya adalah perancangan storyboard. Storyboard bertujuan untuk mempermudah memberikan informasi mengenai alur media yang dikembangkan. Adapun contoh dari story board yang dikembangkan sebagai berikut:

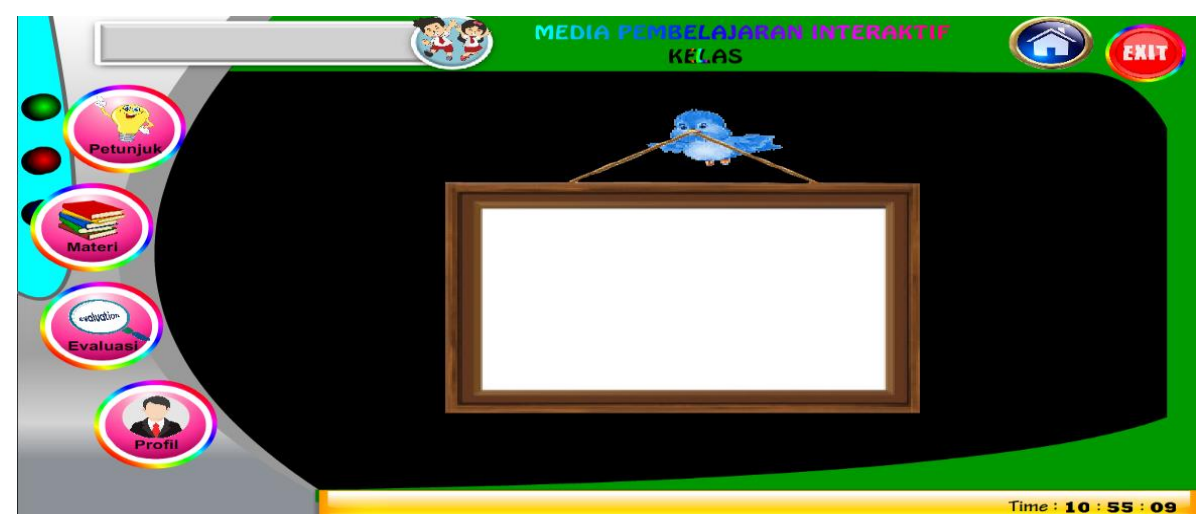

Gambar 2: contoh story board tampilan utama

Setelah dilakukan perancangan terhadap flowchart dan storyboard maka selanjutnya dilakukan pengembangan media. Media yang dikembangkan kemudian dilakukan validasi ahli untuk mengetahui kelayakan media. Pakar ahli yang digunakan adalah pakar ahli materi dan pakar ahli media. Adapun hasil validasi dari pakar ahli materi sebagai berikut:

Tabel 4. Rekapitulasi Validasi Ahli Materi

\begin{tabular}{lcccc}
\hline \multirow{2}{*}{ Indikator } & \multicolumn{2}{c}{ Validasi Pertama } & \multicolumn{2}{c}{ Validasi Kedua } \\
\cline { 2 - 5 } & Validator 1 & Validator 2 & Validator 1 & Validator 2 \\
\hline Aspek kelayakan isi & 53 & 55 & 81 & 83 \\
\hline Aspek kelayakan bahasa & 50 & 54 & 82 & 82 \\
\hline Aspek kelayakan penyajian & 51 & 52 & 83 & 83 \\
\hline Rata-rata & 51,33 & 53,67 & 82,00 & 82,67 \\
\hline Kategori & Cukup Valid & Cukup Valid & Sangat Valid & Sangat Valid \\
\hline
\end{tabular}

Dari tabel 4 berikut dapat dilihat bahwa pada validasi pertama pakar ahli mengkategorikan media pembelajaran yang dikembangkan cukup valid. Ada beberapa hal yang perlu diperbaiki yaitu ada beberapa 
bahasa yang perlu disederhanakan, memperluas aspek kemandirian, dan perlunya menggunakan background dengan warna yang tidak mencolok. Kemudian saran tersebut ditindak lanjut dan dilakukan validasi kedua dengan penilaian akhir pada aspek materi dengan kategori cukup valid. Sedangkan untuk penilaian aspek media dapat dilihat pada tabel berikut:

Tabel 5. Rekapitulasi Validasi Ahli Media

\begin{tabular}{llllll}
\hline \multirow{2}{*}{ Indikator } & \multicolumn{2}{c}{ Validasi Pertama } & \multicolumn{2}{c}{ Validasi Kedua } \\
\cline { 2 - 6 } & Validator 1 & Validator 2 & Validator 1 & Validator 2 \\
\hline Aspek desain & 55 & 54 & 83 & 82 \\
\hline Aspek usability & 53 & 56 & 82 & 84 \\
\hline Aspek typografi & 54 & 54 & 83 & 84 \\
\hline Aspek strategi & 56 & 53 & 85 & 83 \\
\hline Rata-rata & 54,50 & 54,25 & 83,25 & 83,25 \\
\hline Kategori & Cukup Valid & Cukup Valid & Sangat Valid & Sangat Valid \\
\hline
\end{tabular}

Kategori Cukup Valid Cukup Valid Sangat Valid Sangat Valid.

Dari tabel 5 berikut dapat dilihat bahwa pada validasi pertama aspek media, pakar ahli mengkategorikan media pembelajaran cukup valid. Namun ada beberapa hal yang harus perbaiki yaitu perlunya perbaikan pada penggunaan jenis huruf dan ukuran huruf, menyelaraskan pengoperasian media agar lebih sederhana dan memperbaiki beberapa huruf yang typo. Setelah semua saran pakar ahli di perbaiki maka selanjutnya dilakukan validasi kedua dan dikategorikan sangat valid.

Berdasarkan validasi kedua dari aspek materi dan media mendapatkan kategori sangat valid. Hal ini dapat disimpulkan bahwa media pembelajaran berbasis teknologi dengan bantuan adobe flash cs6 sangat layak untuk digunakan pada siswa sekolah dasar selama proses pembelajaran di masa pandemic covid-19 ini. Hasil penelitian ini didukung oleh penelitian sebelumnya. Peneltian yang dilakukan oleh Meylinda (2016) yang menyatakan telah dikembangkan media pembelajaran untuk meningkatkan keterampilan berbicara siswa SD dengan menggunakan adobe flash yang valid dan praktis. Selain itu penelitian yang dilakukan oleh Maulidta and Sukartiningsih (2018) yang menyatakan bahwa telah dikembangkan media pembelajaran untuk meningkatkan keterampilan menulis teks eksposisi siswa SD dengan menggunakan adobe flash yang valid. Penelitian lainnya yang dilakukan oleh Widyastuti et al (2018) menyatakan bahwa telah dikembangkannya media pembelajaran dengan bantuan adobe flash pada materi bumi dan alam semesta untuk siswa SD yang valid. Dari penelitian sebelumnya ditemukan bahwa telah dikembangkan media pembelajaran dengan bantuan adobe flash yang valid. Terdapat kesesuaian antara penelitian tersebut yaitu media pembelajaran berbasis teknologi dengan bantuan adobe flash cs6 dikembangkan dengan tingkat kategori valid. Namun pada penelitian ini menjadi temuan yang berbeda yaitu pengembangan media pembelajaran ini disesuaikan dengan kondisi pembelajaan pada masa pandemi covid-19 yang menuntut kemandirian belajar. Media yang dikembangkan didesain dengan memperhatikan aspek-aspek kemandirian belajar dengan memperhatikan konsep belajar dari rumah. Hal ini lah yang menjadi temuan baru dalam penelitian ini.

Penelitian ini memiliki keterbatasan yaitu materi yang dikembangkan hanya untuk tema 5 pada proses pembelajaran di kelas V. Sehingga penyebaran produk ini hanya sebatas untuk kelas V pada tema 5. Diperlukan lagi penelitian lanjutan untuk dapat mengembangkannya pada setiap level pendidikan disekolah dasar. Penelitian ini dapat dijadikan sebagai referensi bagi praktisi pendidikan untuk mengembangkan proses pembelajaran pada masa pandemic covid-19. Selain itu dengan dikembangkanya media pembelajaran ini dapat meningkatkan kualitas pembelajaran disekolah dasar pada masa pandemic covid-19. 
2147 Pengembangan Media Pembelajaran Berbasis Teknologi Berbantuan Adobe Flash Cs6 untuk Pembelajaran Pada masa pandemi Covid-19- Lola Afriyani, Yanti Fitria

DOI : https://doi.org/10.31004/edukatif.v3i4.1171

\section{KESIMPULAN}

Penelitian ini menyimpulkan bahwa telah dikembangkanya media pembelajaran berbasis teknologi dengan bantuan adobe flash cs6 yang dikategorikan sangat valid. Hal ini membuktikan bahwa media pembelajaran tersebut sangat layak untuk dikembangkan.

\section{UCAPAN TERIMA KASIH}

Ucapan terimakasih kepada Universitas Negeri Padang yang telah memberikan ijin untuk melaksanakan penelitian ini.

\section{DAFTAR PUSTAKA}

Aji, R. H. S. (2020). Dampak Covid-19 Pada Pendidikan Di Indonesia: Sekolah, Keterampilan, Dan Proses Pembelajaran. Salam: Jurnal Sosial Dan Budaya Syar-I.(7), 5, 395-402.

Astini, N. K. S. (2020). Pemanfaatan Teknologi Informasi Dalam Pembelajaran Tingkat Sekolah Dasar Pada Masa Pandemi Covid-19. Lampuhyang, 11(2), 13-25.

Fauziah, I. Z. (2016). Pengembangan E-Modul Berbasis Adobe Flash Cs6 Pada Mata Pelajaran Penataan Barang Dagang. Jpbm (Jurnal Pendidikan Bisnis Dan Manajemen), 2(2), 154-159.

Galea, S., Merchant, R. M., \& Lurie, N. (2020). The Mental Health Consequences Of Covid-19 And Physical Distancing: The Need For Prevention And Early Intervention. Jama Internal Medicine, 180(6), 817818.

Gunawan, G., Suranti, N. M. Y., \& Fathoroni, F. (2020). Variations Of Models And Learning Platforms For Prospective Teachers During The Covid-19 Pandemic Period. Indonesian Journal of Teacher Education, 1(2), 61-70.

Hendri, S., Handika, R., Kenedi, A. K., \& Ramadhani, D. (2021). Pengembangan Modul Digital Pembelajaran Matematika Berbasis Science, Technology, Enginiring, Mathematic Untuk Calon Guru Sekolah Dasar. Jurnal Basicedu, 5(4), 2411-2420.

Jones, N. R., Qureshi, Z. U., Temple, R. J., Larwood, J. P., Greenhalgh, T., \& Bourouiba, L. (2020). Two Metres Or One: What Is The Evidence For Physical Distancing In Covid-19?. Bmj, 370.

Lestari, A. F., Amalia, H., \& Puspita, A. (2021). Penerimaan Teknologi Zoom Cloud Meeting Terhadap Minat Belajar Siswa Dari Rumah Dengan Tam. Inovtek Polbeng-Seri Informatika, 6(1), 27-36.

Maulidta, H., \& Sukartiningsih, W. (2018). Pengembangan Media Pembelajaran Interaktif Berbasis Adobe Flash Untuk Pembelajaran Menulis Teks Eksposisi Siswa Kelas Iii Sekolah Dasar. Jurnal Penelitian Pendidikan Guru Sekolah Dasar, 6(5), 1-10

Meylinda, F. (2016). Pengembangan Media Pembelajaran Keterampilan Berbicara Dengan Program Adobe Flash Untuk Siswa Kelas V Sd. Jurnal Review Pendidikan Dasar: Jurnal Kajian Pendidikan Dan Hasil Penelitian, 2(3), 256-264.

Miaz, Y., Kenedi, A. K., Monafajri, W. S., \& Helsa, Y. (2019). Educative Learning Media For Elementary School Students. Advanced In Social Science, Education And Humanities Research, 382, 722-727.

Muyaroah, S., \& Fajartia, M. (2017). Pengembangan Media Pembelajaran Berbasis Android Dengan Menggunakan Aplikasi Adobe Flash Cs 6 Pada Mata Pelajaran Biologi. Innovative Journal Of Curriculum And Educational Technology, 6(2), 22-26.

Ningsih, S. (2020). Persepsi Mahasiswa Terhadap Pembelajaran Daring Pada Masa Pandemi Covid19. Jinotep (Jurnal Inovasi Dan Teknologi Pembelajaran): Kajian Dan Riset Dalam Teknologi Pembelajaran, 7(2), 124-132. 
2148 Pengembangan Media Pembelajaran Berbasis Teknologi Berbantuan Adobe Flash Cs6 untuk Pembelajaran Pada masa pandemi Covid-19- Lola Afriyani, Yanti Fitria

DOI : https://doi.org/10.31004/edukatif.v3i4.1171

Nopitasari, E., Rahmawati, F. P., \& Ratnawati, W. (2021). Peningkatan Hasil Belajar Matematika Melalui Model Pembelajaran Blended Learning Berbasis Blog Pada Peserta Didik Di Sekolah Dasar. Edukatif: Jurnal Ilmu Pendidikan, 3(5), 1941-1950.

Pakpahan, R., \& Fitriani, Y. (2020). Analisa Pemanfaatan Teknologi Informasi Dalam Pembelajaran Jarak Jauh Di Tengah Pandemi Virus Corona Covid-19. Journal Of Information System, Applied, Management, Accounting And Research, 4(2), 30-36.

Rahmaibu, F. H., Ahmadi, F., \& Prasetyaningsih, F. D. (2016). Pengembangan Media Pembelajaran Menggunakan Adobe Flash Untuk Meningkatkan Hasil Belajar Pkn. Jurnal Kreatif: Jurnal Kependidikan Dasar, 7(1), 1-10.

Ramdani, A., Jufri, A. W., \& Jamaluddin, J. (2020). Pengembangan Media Pembelajaran Berbasis Android Pada Masa Pandemi Covid-19 Untuk Meningkatkan Literasi Sains Peserta Didik. Jurnal Kependidikan: Jurnal Hasil Penelitian Dan Kajian Kepustakaan Di Bidang Pendidikan, Pengajaran Dan Pembelajaran, 6(3), 433-440.

Rezeki, S. (2018). Pemanfaatan Adobe Flash Cs6 Berbasis Problem Based Learning Pada Materi Fungsi Komposisi Dan Fungsi Invers. Jurnal Pendidikan Tambusai, 2(2), 856-864.

Salsabila, U. H., Sari, L. I., Lathif, K. H., Lestari, A. P., \& Ayuning, A. (2020). Peran Teknologi Dalam Pembelajaran Di Masa Pandemi Covid-19. Al-Mutharahah: Jurnal Penelitian Dan Kajian Sosial Keagamaan, 17(2), 188-198.

Sari, I. K. (2021). Blended Learning Sebagai Alternatif Model Pembelajaran Inovatif Di Masa Post-Pandemi Di Sekolah Dasar. Jurnal Basicedu, 5(4), 2156-2163.

Siripongdee, K., Pimdee, P., \& Tuntiwongwanich, S. (2020). A Blended Learning Model With Iot-Based Technology: Effectively Used When The Covid-19 Pandemic?. Journal For The Education Of Gifted Young Scientists, 8(2), 905-917.

Soewardini, H. M. D.,Et Al. (2021). Kajian Lintas Perspektif Ilmu Tentang Pandemi Covid 19. Jakarta: Penerbit Qiara Media.

Swalaganata, G. (2018). Pengembangan Media Pembelajaran Game Aritmatika (Gametika) Menggunakan Adobe Flash Cs6. Jurnal Tadris Matematika, 1(1), 1-65.

Widiyastuti, N., Slameto, S., \& Radia, E. H. (2018). Pengembangan Media Pembelajaran Interaktif Menggunakan Software Adobe Flash Materi Bumi Dan Alam Semesta. Perspektif Ilmu Pendidikan, 32(1), 77-84.

Yusuf, A. M. (2015). Pengembangan Media Pembelajaran Berbasis Adobe Flash Untuk Mata Kuliah Fisika Modern Materi Radiasi Benda Hitam. Jurnal Sains Dan Pendidikan Fisika, 11(1), 57-71

Zainuddin, Z., \& Sama, S. (2020, September). Keragaman Sistem Pembelajaran Di Masa Covid-19 Pada Sekolah Dasar Kecamatan Ambunten Kabupaten Sumenep. In Prosiding Seminar Nasional Pendidikan Biologi. 